\title{
The Role of Bureaucracy in Democratic Governance in Nigeria: Relevance and Evidence from Akwa Ibom State (1999-2017)
}

\author{
Victor E. Ita \\ Department of Political Science \\ Akwa Ibom State University, Obio Akpa Campus, Oruk Anam LGA, Nigeria \\ David A. Titus \\ Department of Political Science \\ Evangel University, Akaeze, Ebonyi State, Nigeria
}

Received: May 2, 2018 Accepted: July 6, 2018 Online published: July 23, 2018

doi:10.5296/jpag.v8i3.13305 URL: https://doi.org/10.5296/jpag.v8i3.13305

\begin{abstract}
The paper examined how bureaucracy, as the legitimate organ for the implementation of state policies and programmes, has enhanced democratic governance in Nigeria using Akwa Ibom State as a reference point. The paper attempted to analyze the interplay between the political concept of democracy and bureaucratic practice in the State. The basic assumption of the paper was that democratic governance can be enhanced through effective and efficient bureaucracy. Based on documentary analysis with a tinge of survey (interview) method, it was observed that bureaucracy in Akwa Ibom has shown reasonable evidence of involvement in the implementation of government policies and programmes towards the welfare of the citizenry in demonstration of good governance. Moreover, the paper noted that the State bureaucracy needed to be repositioned to tackle some negative tendencies such as poor attitude to work, improper postings and placement of employees to positions of responsibilities and corrupt practices among public officials. Given these findings, it was recommended, among others, that the principles of transparency, probity and accountability should be made paramount as a norm and in praxis within and without the State bureaucracy; that meritocracy should constitute the basis for recruitments/appointments and postings within the civil service. These would enhance the effectiveness and efficiency of the bureaucracy towards democratic governance.
\end{abstract}


Keywords: bureaucracy, democratic governance, majority rule, policies, political leadership

\section{Introduction}

In contemporary world, democracy have been universally accepted as the best system of government, which depends absolutely on strict adherence to laid down rules, orders, processes, procedures and practices. Obviously, the greatest problem confronting Nigeria's post-independent era is that of good governance. Having experienced transition from colonial autocracy to independence and civil rule in 1960, Nigeria was perceived as one country in the West African sub-region that would possibly make steady progress towards good governance and consolidated democracy through effective bureaucratic involvement in affairs of governance. Sad enough, this hope failed owing to military incursion into Nigeria's politics since 15 January 1966 which resulted to nine (9) military regimes and three (3) disjointed democratic experiments before the final enthronement of democratic rule on 29 May 1999. The country, in effect, has experienced bad governance, massive corruption, criminal denials of fundamental human rights of the citizenry, economic deprivations from both greedy political leaders and military dictators and ineffective bureaucracy.

Notably, Nigeria's brand of democracy lacks the attributes of a conventional democracy. It is not, therefore, unpatriotic to say that what has been in practice in Nigeria since the dawn of the Fourth Republic is both artificial and cosmetic democracy. This is actually because the policies and actions of some Nigerian leaders at all levels of government point to violations of conventional democratic norms. According to Akpan-Umana (2003:6) "these ugly developments would make a keen observer of the political climate in the country to write off democracy". Nevertheless the process of democratic governance and consolidation is a complex one. It is a process in which all major political actors come to accept and diligently adhere to the democratic rules of the game. Indeed every organization, institutions and the citizenry must be part of the democratic process that will enhance the entrenchment of democratic culture and practices.

Certainly, as MacOgonor and Okodudu (2007:183) opined, "in every nation or state, the legitimate organ for addressing the valid public interest of the state are the bureaucracies or public service institutions". This function is performed through the implementation of government policies and programmes effectively and professionally. Whether the citizens of a state can live happily and orderly devoid of much conflicts and confusion may be determined to a large extent by good governance exemplified by timely and efficient service delivery by the public service to the people. This is expected of all democratic governments, because good governance implies government that incorporates the features of accountability of public official, transparency in government procedures and processes, reliable flow of information to the citizenry, freedom of press and adherence to the rule of law (Akanbi, 2004).

In embarking on investigation on the bureaucracy-democracy linkage, a number of challenges emerged for the researchers as the two terms are enmeshed in multiplicity of definitions, interpretations and usages by scholars and political analysts. Particularly, the literature on bureaucracy continues to suffer from several weaknesses. The first is that it has thus far been 
unsuccessful in accommodating bureaucracies as responsive to their structural environment with their capacity to operate as autonomous actors and has failed to reflect on the dual nature of bureaucracies as both government's institutions and agents of transformation. The second concerns the lack of accumulative power of the various co-existing models of bureaucracy and the shortcomings in the attempts to elaborate new models and typologies. Finally, the literature on bureaucracies continues to be poorly developed theoretically, especially on the subject of the contribution and relevance of bureaucracies to the democratic governance, and their place in contemporary democracies more generally.

Ultimately, the paper attempts to analyze the interplay between the political concept of democracy and bureaucratic practices in Nigeria using Akwa Ibom State as a reference point. The paper is based on the proposition that successful implementation of government policies and development programmes depend on the degree of efficiency and effectiveness of the bureaucracy. Pragmatically, this is because democracy ensures good governance through effective implementation of policies by the state's bureaucracy. Put differently, implementation of government policies and programmes depend extensively on the bureaucracy, hence, the importance of bureaucracy to democratic governance. But the question is: has bureaucracy in Nigeria lived up to its expectations? The above problematic precipitated the objectives of this paper which, ideally, were:

(i) To establish the relationship between democracy and bureaucracy.

(ii) To examine how bureaucracy enhances democratic governance through implementation of government policies and programmes.

(iii) To offer suggestions towards repositioning bureaucracy against certain vices for effective and efficient bureaucratic practices in Nigeria generally and Akwa Ibom State specifically.

Significantly, it is the researchers' believe that the analysis in the paper will contribute, academically, in establishing the nexus between bureaucracy and democratic governance in the state as well as enlarge the theoretical base and body of existing knowledge in the area of bureaucracy and democratic governance. Also, the paper will be of practical importance to political leaders, bureaucrats of different cadres and public administrators by providing clear perspectives for their understanding of their roles and involvement in the management of government businesses towards the attainment of good governance and provision of democratic gains to the citizenry. Incidentally, the role of bureaucracy in Akwa Ibom State as a determinant of social, political and economic changes will be subjected to systematic analysis to discern its activities as the product of larger social, political and economic forces which conditions the content, scope and incidence of democratic practice and governance in the state.

\section{Bureaucracy Elucidated}

According to Naidu (1996), bureaucracy was first used in the French form "bureaucratique" by a French economist and Minister of Commerce, Monsieur Vincent de Gourney in 1745. The term spread to Germany during the nineteenth century as "burokratie" and has since 
found its way into English and many other languages. It is derived from the word "bureau" meaning an office and a desk - a term derived from the Greek word meaning "to rule". Bureaucracy is thus the rule of officials.

As a matter of scholarly enquiry, the term is primarily associated with Max Weber (1864-1920), a famous German Social Scientist (Sociologist). Weber used the word to describe a rationalistic and efficient organization of government, administration, and industry. In essence, the Weberian conception equates "an ideal type of bureaucratic organization" with "administrative rationality". His ideas on bureaucracy were embedded in his broader theory of the rationalization process. Bureaucracy was thus defined as "the means of carrying 'community action' over into 'rationally ordered' societal action” (Frank 2007:35).

According to Page (1988), there are at least four meanings of bureaucracy. First, bureaucracy as a system of rule; this meaning which closely resembles its semantic origin sees bureaucracy as a governmental system in which officials dominate; second, bureaucracy as a code of conduct which is based upon the application of general rules; third, the concept of bureaucracy as efficiency or inefficiency. Bureaucracy could be seen as resulting in greater efficiency in the performance of organizational tasks or as inefficiency as it involves unnecessary rules and procedures, and the stifling of all initiatives by using these rules and procedures actually to block them; lastly, bureaucracy can refer to a social group - those who work in bureaus (offices), be it in the public or private sector. More frequently, it is used to apply to office workers in the organizations, especially public servants.

For Ritzer (1996), bureaucracy is largely a creation of the modern western world. Though earlier societies had organizational structure, they were not as effective as present day bureaucracy. Hence, Ritzer (1996:17-20) poignantly observed that:

A bureaucracy is a large-scale organization composed of a hierarchy of offices. In these offices people have certain responsibilities and must act in accord with rules, written regulations and means of compulsion exercised by those who occupy higher level positions. Ultimately, the bureaucracy differ from earlier methods of organizing work because it has a formal structure that among other things allows for greater efficiency, institutionalized rules and regulations, lead, even force, those employed in the bureaucracy to choose the best means to arrive at their ends. A given task is broken up into a variety of components with each office responsible for a distinct portion of the whole task. Incumbents of each office handle their part of the task (usually following present rules and regulations).

Along this viewpoint, Thompson (1961) characterized bureaucratic organizations as composed of a highly elaborated hierarchy of authority. Striking the same chord, Naidu (1996:80-81) asserted that:

Freed from its derogatory sense, bureaucracy actually refers to any large-scale organization of appointed officials whose primary function 
is to implement the policies of the decision-makers. It denotes a complex system of men, offices, methods and authority which large scale organizations employ. Bureaucracy is a type of organization designed to accomplish large-scale administrative tasks by systematically coordinating the work of many individuals in organized structure that puts laws and policies into effect effectively and efficiently.

In the modern nation-states, bureaucracy is the dominant form of organization in the public sector. It has occupied a significant place in contemporary society. It fulfils many needs in the society. It activities affect social, political, and economic aspect of human life. Most of today's societies and their governments have come to rely on bureaucracy to accomplish administrative tasks. Whatever the system of government, bureaucracy is essential as the machinery for the implementation and execution of policies, programmes and governmental decisions. It is through bureaucracy that modern governmental authority becomes actual practice. It is in this context that this paper examined the role and relevance of bureaucracy in democratic governance with evidence from Akwa Ibom State in the Fourth Republic (1999-2017).

\section{On the Concept of Democracy}

The term "democracy" is as copious as it is confusing. According to Erunke (2012), democracy is a fluid concept that has received many definitions by scholars either in the classical political studies or in the contemporary world of scholarship. Hence, democracy has refused to subject itself to any one sentence or universally acceptable definition as they are definitions, postulations, interpretations and operationalizations as there are writers, analysts and authors on the concept. In a rather simplistic manner, Abraham Lincoln, the 16th American President, in his Gettysburg address of 19 November 1963, defined democracy as the government of the people, by the people and for the people. For Cohen (1971) democracy is that system of community government in which by and large the members of the community participate or may participate directly in the making of decision on matters which affect them all. The above views depict the notion of equality and direct participation, implicit in Greek version of direct democracy. However, the modern democracy concerns citizens' participation through elected representatives and majority rule. Along this argument, Shively (2001:160) defined democracy as "a state in which all fully qualified citizens vote at regular intervals to choose, among alternative candidates, the people who will be in charge of setting the state's policies".

For Locke (1965), the progenitor of modern and liberal democracy, democracy is "a rule by the majority; a government arising from the majority of men uniting into a whole power of the community and employing all the power in making laws by officers of their own appointing”. Satori (1965:17-18) refined Locke's definition of democracy and conceptualized it as "the rule of the entire people who are the source of the political power of the government of the day". According to Eminue (2005:282), the term 'democracy' from the Greek derivation of it, meant rule by the people; hence: 
Democracy is government of the people by the people, although the extent to which the people can actually govern will vary tremendously from society to society. To a significant degree, a democratic government must rest on the consent of the governed and its policies must be responsive to their desires.

Based on the conception above Eminue, 2005:282), put forward an operational definition of democracy as: "a form of government organized in accordance with the principles of popular sovereignty, political and economic equality, popular consultation and majority rule".

In similar vein, Omotola (2004:20) conceived democracy as "both moral imperative that represents a permanent aspiration of human beings for freedom, for a better social process and a continuous process of promoting equal access to fundamental human rights, civil liberty for all and a political practice or a mode of governance based on the principles of popular sovereignty, the rule of law, accountability and participation. In a rather simple way Heater (1964:20) defined democracy as "as essential method of organizing society politically". In addition he identifies five basic elements that differentiate a democratic society from undemocratic ones. These includes: equality, sovereignty of the people, respect for human rights, rule of law and liberty of individuals. For Diamond (1989:46) "democracy entails meaningful and extensive competition among individuals and organized group either directly or indirectly, for the major position of governmental power".

\section{Linkage between Democracy and Bureaucracy}

The concept of democracy has been conceptualized differently by some authorities based on their intellectual orientations and perspectives. From the liberal perspective, acclaimed to be universally accepted model of governance, democracy is seen to be a set of values which principally include rule by elected representatives, universal adult-suffrage, and respect for human rights and so on. Along the same line of argument, Held (1993) conceived democracy as a cluster of rules and institution permitting the broader participation of the majority of citizens in the selection of representatives who alone can make political decisions. It therefore implies that democracy has to do with governance of the society through massive participation of the people in the democratic process and equitable and justifiable distribution of resources.

According to Akanbi (2004) good governance means government that incorporates the feature of accountability of public officials, transparency in government procedures and processes, reliable flow of information to the citizenry, freedom of the press and adherence to the rule of law. Frankly speaking, the legitimate organ for addressing the valid public interest in the democratic process of the state is the bureaucracy, or public service institutions. This function is performed by implementing the policies of government efficiently and professionally, being that public policies are integrated programmes of action which an actor (or a group of actors) is accustomed to or intends to undertake in response to given problems or situations with which he is confronted (Ikelegbe, 2006). Therefore, since the bureaucracy is the machinery through which government implements its policies and programmes, the bureaucracy remains permanent for continuity of government within the state. The political 
office holders 'come and go' based on their democratic tenure. They take political decisions and design developmental programmes in the state, but it is the duty of bureaucrats to supply the political appointees with the information necessary to make a right decision. Once the decision is taken, the bureaucrats must carry out loyally the policy chosen, even though they may prefer a different one. Hence, the bureaucracy or the civil service is the machinery through which the government sets out to achieve its objectives and ensure its success.

Therefore, the linkage between democracy and bureaucracy lie on the fact that while bureaucracy ensures the continuity and growth of democracy through implementation of government policies and development programmes, democracy on the other hand exclusively design the bureaucracy within a state. The Akwa Ibom State government for instance, determines the number of ministries and the size of its workforce to ensure optimal productivity.

\section{Theoretical Framework}

This paper adopted Henri Fayol's (1930) organizational theory as its theoretical framework of analysis. According to Pugh (1966), organizational theory underscores the study of the structure and functioning of organizations and the behaviour of groups and individuals within them. The theory holds that any organization, whether small or large, should be designed in accordance with some principles which include hierarchical structure, order, established rules and regulations, impersonality of interpersonal relations, clarity and orderliness of purpose, defined objectives, among others. These constitute the hallmark of bureaucracy as advocated by Max Weber (1957) in his ideal type construct. The stability of the bureaucratic administration is promoted by deliberate design of the political class. Paradoxically, while the bureaucracy or the civil service is set up and sustained by the political leadership, the latter is more often than not survived by the bureaucracy itself. However, in conventional administrative thought, the civil service (bureaucracy) is an instrument both for policy advice and for the implementation of the will of the state as determined by legitimate political institutions to which the service must be both subordinate and subservient (Olugbemi, 1979). This precipitated the clamour for subordination of the bureaucracy to political control, which often creates confusion in administrative procedure and tangled the people-centred approach to development of most democratic governments.

It is on the strength of the above argument that organizational theory is deemed appropriate as a theoretical framework in the analysis of bureaucracy and democratic governance in Nigeria's Fourth Republic using Akwa Ibom as a reference point.

\section{Bureaucracy and Governance in Akwa Ibom State: A Historical Sketch}

Bureaucracy in Akwa Ibom State is a brainchild of Nigeria's bureaucracy. The Nigerian bureaucracy has gone through three phases: these are: the era of "Administrative Unitarianism" (1914-1946), the era of "Decolonization and Regional Decentralization" (1946-1966) and the era of "New Federalism" under military interregnums and the 1979 presidential constitution (Nwosu 1985). The fourth phase is the current civilian dispensation, with emphasis on effective and efficient public service (Obi and Nwanegbo, 2006). 
Commenting on these phases, Eteng (1987) saw the first one as an era of experimentation in unitary civil service, during which the main objectives of the colonial civil service included:

(a) Law and order maintenance in terms of pacification and control of the natives and the consolidation of the British colonial administration.

(b) The administration of such scattered technical and professional departments as education, health, agriculture, treasury, forestry, public works and audits.

(c) Resource mobilization especially in terms of programmed intensification of export production of cash crops which included cocoa, palm produce, groundnuts, cotton, timber, rubber, tin, coal, and other minerals.

The second phase (1946-66) was the era of decolonization and regional decentralism; this era witnessed the regionalization of politics in Nigeria which was as a result of the introduction of Richard constitution in 1946, the Macpherson constitution of 1951 that brought the country closer to a federal structure and the Lyttleton constitution of 1954 that effectively made Nigeria a federal state. Consequent upon the above, federal and regional civil services were created in 1954. The development in this period had far reaching consequences; firstly, the entrenchment, consolidation and growing pre-eminence of regional governments and their respective public services over the federal government and its services; secondly, the quickening pace of the Nigerianization of the public service and its differential manifestation in the federal and the regions (such as the Northernization policy); thirdly, the development of regional public services as executive arms of the regional parties-in-power under the firm control of the regional major ethnic formations; fourthly, an attempts at regional development within the context of the colonial ten-year plan for development and welfare (1946-1956), and finally, the institutionalization of communalistic and primordial forces within the regions (Obi and Dalhatu, 2007).

The third phase, dubbed the era of "New Federalism", covered the period preceding the Nigerian civil war, the Second Republic and the era of military rule. This era was marked by certain features which included:

(a) Increased centralization of political authority especially over economic and political matters.

(b) The ascendancy of contrived centripetal forces which institutionalized the increasing dominance of the federal over state governments.

(c) Greater structural differentiation of the constituent states through the creation of local government areas and senatorial zones.

(d) Increased federal government largesse from oil proceeds and its dominant distributive capacity and control over the increasingly dependent states.

(e) Increased functions of the federal and state civil services following the demise of the regional structures, the creation of states from twelve to nineteen between 1967 and 1976. 
(f) The rise of militaristic bureaucracy resulting from the civil war operation, the proscription of political parties and the confirmation of the supremacy of the federal over state and local government civil services in the formulation, planning and implementation of national development plans and programmes.

The fourth and present phase in the evolution of the Nigerian public service is the present civilian dispensation. The government has adopted "reform" policies that are clearly World Bank/IMF sponsored and which are geared toward making Nigeria a market economy. In terms of the public sector, the key features of the reforms are: privatization/commercialization, a leaner civil service and cutting cost. The reforms can well be situated within the ambit of the concept of New Public Management (NPM). According to Adamolekun (2002), the NPM is a new approach to public administration that relies on the use of private sector techniques and principles in the management of public sector activities. The concept seeks to apply market principles to governmental administration with emphasis on completion, contracting and consumer orientation. It also emphasizes merit-based recruitment and promotion and increased autonomy for managers with corresponding responsibilities performance related, pay and continuous skills development and up-grading. Thus, the administrative reform package of the government has come to contain such policies and programmes as monetization, participatory pension scheme, etc. (Obi and Nwanegbo, 2006).

In the light of the above, the bureaucratic machinery of Akwa Ibom State (Civil Service) came into existence as a result of the creation of the state, with its capital in Uyo, from the erstwhile Cross River State on 23 September 1987 by the then Military President and Head of State, General Ibrahim Badamosi Babangida. The creation of the state was later given legal backing with the promulgation of Degree No. 24 of 1987. The state occupies the South-East corner of Nigeria's territorial expanse. It lays between latitudes $4^{0} 31^{!}$and $5^{0} 33^{!}$North and longitudes $7^{0} 35^{!}$and $8^{0} 25^{!}$East. The state is bounded on the East by Cross River State, on the North by Abia State and on the South by Atlantic Ocean. The State occupies a total landmass of 7245.935 square kilometres with a population of about four million people (NPC, 2006).

The Akwa Ibom State civil service is part of the executive branch of the state government. The staff strength of the service stood at 16,643 (as at 2015) and spread across twenty-one (21) ministries, bureaus and agencies, namely: Ministries of Justice; Agriculture and Food Sufficiency; Finance; Works; Education; Environment; Transport and Petroleum Resources; Local Government and Chieftaincy Affairs; Lands and Town Planning; Information and Strategy; Health, Science and Technology; Women Affairs and Social Welfare; Youth and Sports; Housing and Special Duties; Economic Development, Labour and Manpower Planning; Investment, Commerce and Industries; Culture and Tourism; the Bureau of Political/Legislative Affairs and Water Resources; Bureau of Rural Development and Cooperatives, as well as Roads and Other Infrastructure Maintenance Agency (AKSG, 2016).

\section{The Relevance of Bureaucracy to Democratic Governance in Akwa Ibom State}

Sine it is the civil service (bureaucracy) machinery that is mainly responsible for the execution and implementation of government policies and programmes, it follows that the 
success or effectiveness of any government depends largely on the public/civil service, especially its efficiency and ability to respond quickly to governmental tempo. Therefore, bureaucracy occupies an important place in the functioning of the Nigerian public/civil service. Outstandingly, the relevance of bureaucracy in Akwa Ibom State is manifested in a number of ways, including the followings:

i. The civil service is the main instrument that mirrors the image of government to the governed. Only a few citizens and perhaps top politicians, that will come into direct contact with the Governor, and the Commissioners in the state. It is with the public service departments that the generality of the pubic have business to transact. Matters like obtaining and issuance of forms for certain purposes, obtaining licenses, inspection of farms and schools, supply of drugs in hospitals, dispensaries and maternity centres and a host of other services are performed by the civil servants or the bureaucrats in the state. The public, in most part, form their impressions and conceptions of the power and authority of government from the acts of the bureaucrats.

ii. The civil service serves as the repository of knowledge and experience in government. In Akwa Ibom State, the civil service controls expertise and information. The result is that all succeeding governments depend on the bureaucrats for the supply of information and advice which have been accumulated in records and files and in the experience of long-serving officials. In essence, the political class depends on the bureaucrats for the needed information and expertise in the discharge of the duties of government. This is so because the bureaucrats have the time to work on the mass of records and information for that is precisely what they are employed to do.

iii. Through the instrumentality of bureaucracy, the civil service plays the important role of educating new commissioners and 'bringing them in' when they first come to the government. Many politicians come with preconceived ideas, some arrive in the ministries with some ideas or philosophies which they consider to be a wonderful innovation. It is the civil servants who show the commissioner that such ideas are unworkable or that what the commissioner regards as his special innovation has been tried many years before and with what results in the state.

iv. Civil servants at the top echelon do not merely serve as neutral administrators of policies laid down by politicians, or as mere instruments for executing the policies, they are themselves closely involved in the policy-making process because they weigh various alternatives and suggest the best course out of a number of alternative solutions. Even though, constitutionally, it is the legislature that is responsible for making laws, civil servants do have some influence in the legislative process. They assist in drafting proposals which form the basis of policy for the laws. In addition they prepare the rules and regulations made by the executive in the process of executing the laws. 


\section{Macrothink}

Journal of Public Administration and Governance ISSN 2161-7104 2018, Vol. 8, No. 3

v. The top bureaucrats such as Permanent Secretaries and Head of Civil Service serve as advisers to their Commissioners in the state. The civil service stores government information and possesses professional and technical expertise and experience in government business. Armed with these rare attributes, the civil servants are well placed to advice their political masters on complex issues of government.

vi. It is the responsibility of the legislature (Akwa Ibom State House of Assembly) to decide on the amount of taxes to be paid by the people and impose it on them. When these are done, it then becomes the responsibility of the civil service to use appropriate machineries to collect the taxes and other government revenues for the state. Responsible public servants keep accurate account of all incomes and expenditures of government, and audit same regularly.

The foregoing signifies the various aspects in which the Nigerian Government generally and Akwa Ibom State Government specifically performs its duties and roles through the instrumentality of the bureaucracy. Thus, bureaucracy as a state agency finds itself playing the historically determined role of managers of developmental programmes and projects that otherwise would have been left in the hands of the private sector. Consequently, bureaucracy is conceived as being responsible for regulatory and service functions of the state. By generating and coordinating various developmental projects, they serve as instrument of change, innovation and transformation under a democratic government.

\section{Bureaucratic Reforms in Akwa Ibom State}

The major challenge that faced Akwa Ibom State at the emergence of the Fourth Republic was the task of implementing government's reforms which is the most important stage in the planning process. No matter how good and lofty plans may be, development goals cannot be achieved in a democratic set-up without effective implementation. This created the need to make the state public service (bureaucracy) more effective, such that all public servants would be involved in the emerging strategic economic plan towards good governance and development goals in the state. To attain the desired goals, strategic reforms were introduced and implemented within the context of the state bureaucracy. These, among others, included:

Monetization Policy: The Obasanjo led administration in 2004 adopted the monetization policy which was also implemented at the states' level including Akwa Ibom State. Under the public sector reform agenda, monetization refers to the process of converting the erstwhile non-monetary compensation of the public servants into monetary values to be paid to them as per the agreed schedule. However, the above policy was aimed at reducing overhead cost maintenance on government and curbing waste by public servants and avoiding the burden of providing basic amenities to political appointees and public servants. By monetization of all the elements of compensation, it was considered that a lot of waste in the use of public resources would have been reduced and civil servants would develop the habit of economic use of their resources including the plans to own cars, build and furnish their own houses.

Due Process: Due process as initiated in the Fourth Republic and implemented at all levels of government was aimed at ensuring strict compliance with the rules and procedures guiding 
the process of contract invitation, award and implementation. The policy objectives were:

1. To ensure effective management of government resources in the treasury devoid of waste.

2. To ensure a lasting protection of public servants from the hazards of work in a hostile environment.

3. To enhance Nigeria's path to greatness and rapid development by empowering the economy.

4. To ensure public servants' adherence to rules and regulations and procedures in the discharge of their functions.

5. To inculcate discipline in the public service; and

6. To bring about integrity, transparency and accountability in the conduct of government business (Umofia, 2005).

The procedures were meant for contracts considered by the State and Ministerial Tenders Boards. Hence, due process procedures entail the following:

- Advertisement or public announcement of tender notices and request for expression of interest to undertake a contract.

- Submission of tender and bid documents in strict confidence to tenders' board at stipulated periods.

- Opening of tenders and bid documents in the presence of all members of tenders' board.

- Evaluation of quality and cost of tenders based on pre-determined scoring criteria.

- Selection of contractors by tenders' board based on agreed criteria and performance of bids during evaluation.

Privatization: To reposition the public sector, the government privatized some of the ailing companies through the use of core investors. Consequently, the Champion Breweries PLC was reactivated through a core investor. Also, Anchor Insurance Company Limited was privatized and repositioned for improved performance. Some poorly managed government companies were sold out to private investors who reactivated them back into operation. Among these companies were: Qua River Hotels, Akwa Feeds Limited, Palm Mill Industries Ltd, Metro Hotels, Peacock Paints Limited among others (AKSG, 2004).

Target Setting: Target setting involves planning process which rest on advance projection of tasks to be accomplished within a specified period of time, more often by whom and how it is to be accomplished. It is underpinned by the fact that if group effort is to be effective, people should know what they are expected to accomplish and this is essentially the function of planning. This approach underscores the role of management by objectives (MBO) as a means of integrating and synchronizing individual needs and organizational expectations and demands. When properly applied, the approach possesses high potential of encouraging better 
and more desirable attitude suitably for democratic set-up. This necessitated the establishment of Inter-Ministerial Direct Labour meant for implementing certain intervention/targeted programmes in the State (Uya and Okoro, 2002). This was strengthened with the constitution of Inter-Ministerial Direct Labour Co-ordinating Committee to monitor, supervise and evaluate these projects in the state. This initiative yielded positive results with the commissioning of several projects, prominently, road networks, rural electrification, new Governor's lodge, Ibom International Airport, Le-meridien Hotel and Resorts, Flyovers and Specialist Hospital among other projects across the three senatorial districts of the state within the period under study.

\section{Bureaucratic Practice in Akwa Ibom State: Some Negative Observations}

Observably, the general productivity in the state public service has been low consequent upon certain negative factors inherent in the bureaucratic practice in the state. These are hereunder discussed vis-à-vis the ideal features of bureaucracy and the new personnel management agenda:

Recruitments/Appointments into Public Service: Under the bureaucratic principle, recruitments/appointments into the public service should be based on well stipulated and known criteria, which include basic educational qualification, competitive interview and or examination conducted to select the best amongst applicants to fill available vacancies. Unfortunately in Akwa Ibom State, sentiment, nepotism and political consideration constitute the basis for employment in most of the public establishments. The end point of this is that, unqualified persons are recruited and abysmally placed in the public service. In most cases, vacancies are never published or advertised for people to apply. Sometimes, advertisements for jobs are made after recruitments had been concluded and therefore become mere formality. Every top administrator sees public position as an opportunity to reward and compensate his people knowing too well that they will never forgive him if he does otherwise. This does not enhance efficiency in the public service.

Attitude to Work: Attitude to work in simple terms refers to the manner of feeling and behaviour of employees towards work; such feeling and behaviour is a function of judgement or societal opinion which in turn reflects the values of the actor. If we view values as belief that mould our assessment of relative worth or importance of issues on the basis of our effective commitment, then it is fairly safe to argue that the undesirable problem of poor attitude to work is traceable to faulty social value system which places premium on material or monetary gains over and above other consideration, no matter how noble.

There is no gainsaying the obvious that no people or nation who shun hard work ever register impressive development, hence, the need for a fundamental attitudinal change. This was evident by the establishment of "Ethical and Attitudinal Re-orientation Commission" (EARCOM) and most importantly a monitoring committee by the former state governor, Obong (Arc.) Victor Attah, which continue to go round to ensure that civil servants report to work early and close on time in the state. In one of its mobilization efforts at a seminar organized for civil servants in Akwa Ibom State, the then EARCOM boss, Hon. Eseme Eyibo observed that the Civil/Public Service has an important stake in the management of the state. 
He therefore urged civil servants to shed the garment of corruption and other vices that characterized the locust years of the past military administrations. Eyibo (2000:3) asserted further that:

The Public Service is the central machinery of government established to support supreme political authority. It is therefore imperative that you (civil servants) should be carried along to support the determination of his Excellency to make the State a land of fulfilment.

Outside the various workshops, conferences and seminars, EARCOM has been airing different forms of jingles in English, Ibibio, Annang and Oron languages urging civil servants to develop positive working ethics in the State Public Service, and this has yielded commendable results even as it has ensured effective bureaucracy which is a hallmark of democratic governance.

Accountability: The public servants are supposed to render account of all their actions especially their financial transactions. In Nigeria generally and in fact Akwa Ibom State in particular, this is often not the case. The nature and level of corruption that exist in our public service is better imagined than described. In most instances, it involves the exchange of money or material wealth. Decisions exchanged for material wealth or other selfish gains are normally those that are believed to be against public interest. As against the principle of anonymity which entails impersonality of officials in dealing with official matters, when any member of the public refuses to respond to the wishes of a corrupt official, the official will hide his personal interest in impersonal official language that gives the impression that he/she is acting in the public interest whereas he/she is not. Hence, lack of commonly acceptable norms to restrain public behaviour tends to encourage corruption, as allocation of values and implementation of broad policies of government by bureaucrats are likely to be influenced by parochial rather than universal considerations. The establishment of Independent Corrupt Practices and Related Offences Commission (ICPC), Ethical and Attitudinal Re-orientation Commission (EARCOM) and Audit Alarm Committee attest to the persistent corruption amongst bureaucrats in the Nigerian public service in general and Akwa Ibom State in particular. No wonder Achebe (1983) identified corruption as the trouble with Nigeria. The point stressed here is that if public officials or bureaucrats were accountable to the public as required by the public service or bureaucratic features/principles, there should be less incidence of government treasury being looted.

Neutrality, Impartiality and Anonymity: Public office holders worldwide are divided into two main categories. First, are the political office holders (politicians) who come and go, such as the president, governors, members of the legislature, members of the executive and other political appointees. The principles of political neutrality and anonymity do not bind them because they belong to political parties which enabled them to win election. The second category are the public administrators who are permanent staff of government institutions that only leave office on the basis of retirement or other extraneous reasons. These class of public officers are expected to obey the principles of neutrality, anonymity and impartiality in the discharge of their official functions. 
In practice, it is common knowledge that public office holders who are not supposed to be politicians are card carrying party members. As a result of this, they exhibit partiality in the discharge of their daily functions and activities and also expressed their opinions on issues of policy with high degree of recklessness. This is evident in the state, whereby public officers take sides in the discharge of their legitimate official functions. Issues and duties are seen from parochial perspective thereby encouraging inefficiency. This negative situation have resulted to public services being unnecessarily delayed, costing the state huge sums of money and inconveniencing the citizens. This is predicated on the fact that the principles which were to make public servants discharge their functions without fear or favour are not followed to the letter.

Principle of Uniformity: This principle entails that bureaucrats should be consistent in the treatment of issues and individuals who come to them for solution to their problems. But it is well noted that in Nigeria and by extension Akwa Ibom State, because of our values and other inherent factors, bureaucrats now treat individuals and their cases through certain considerations and parameters. Such issues as Statism, ethnicity, level of affluent and political party affiliation constitute some of the factors that receive primacy while attending to issues involving members of the society. Today we hear of concepts like marginalization, quota system being used. As long as issues are considered on the basis of sentiment, emotion, passion, rather than objectivity, then the end point will be inefficiency, ineffectiveness and poor productivity which have detrimental effects on democratic governance and the implementation of government policies and programmes for the benefit of the citizenry.

It has been argued over the years by scholars that a leadership that has its workers at heart by providing conducive working environment, competitive pay package, and promotion of meritocracy over sentiment is likely to have a workforce that could be easily mobilized without much stress (Naidu, 2009). Prior to the present democratic dispensation, the nation was in shambles; morality was too low while in the public service corruption was the order of the day in every sector. The reason was not farfetched. There was no regard for work ethics among leaders, the issue of corruption was alarming thereby encouraging civil servants to join the bandwagon. Fortunately, with the dawn of democracy and adequate attention paid to the importance of the civil service within the context of the New Personnel Management (NPM), the situation is changing for the better.

A patriotic citizen no doubt is a great asset to any nation. Unfortunately, public office holders in Akwa Ibom State (especially the politicians) still see public office as a gold mine for the embezzlement of public funds. However, the NPM seeks to change this mind-set and ensure that the office one is fortunate to occupy should not be treated as a patronage estate where one siphons public money to create a network of few loyal clients and consequently divert money that would have been used for public good to the benefit of the few.

Although a good number of civil servants have appreciated the good gestures and incentives given by the government to motivate them and consequently change their mind-set and re-orientate them positively towards their job some others are still operating with the old mind-set of lethargy and lackadaisical attitude to work. It is on ground that some civil 
servants report for work late and close before time, while others still engage in nefarious activities such as bribery and commercialization of the place of work through trade on various wares during official hours without paying due attention to their work. There is no gainsaying that such attitude is against the philosophy and objective behind the new personnel management (Ita, Edet and Bassey, 2016).

\section{Towards Repositioning Bureaucracy for Effective Democratic Governance in Akwa Ibom State}

The bureaucracy or civil service is undoubtedly the engine that drives the wheel of government. Though the service has overtime been taunted to be ineffective and slow, yet the fact remains that the civil service is the one and only reliable bridge between every old and new governments. It is the stabilizing force and sustaining foundation for continuity of government. The bureaucracy, using its various apparatus, appendages and institutions, makes positive inputs towards the initiation of laudable policies and programmes for the people. The policies and programmes are tailored in line with the vision, policy thrust and agenda of the existing government.

To rejuvenate bureaucracy in Akwa Ibom State at the entrenchment of democracy in 1999, AK-SEEDS document (2004:28) captured the vision statement of the then executive governor of the state, Obong (Ach.) Victor Attah, this way:

Akwa Ibom State is to be transformed into a prosperous, highly educated, technology driven, ethnically harmonious, caring and pace-setting State in Nigeria through the formulation and implementation of strategic policies and programmes for achieving those attributes and for assisting individuals, institutions and communities achieve their optimum potentials.

To achieve the above vision, a committed bureaucracy was necessary. This therefore called for a radical departure from the usual business approach to a new course of action that would lead to the fulfilment of the vision. In line with this spirit, the government approved the payment of 15 percent salary increase to workers with effect from June 2007. Also, to ensure peace and hope for the civil servants as well as restore confidence to the families of the retrenched staff of the former Akwa Ibom State Water Corporation, the government approved that they be re-absorbed into the service - an initiative that brought an end to the legal tussle between the workers union and the state government. This did not only encourage the seemingly frustrated workers, it also enhance productivity among them. Aside from this, the government maintains prompt payment of staff salaries and entitlements.

Moreover, in realization of the enormous responsibilities expected of the Civil Service, the succeeding government under Chief Godswill Akpabio, pledged to effectively reposition the State Civil Service to be proactive, efficient, people-centred and result-oriented as well as to lubricate the service (the engine) in order for it to spin the wheel of the government at the dire need of transformation (Akpabio, 2007). Hence, in the area of human resource development, the state government exposed all the Permanent Secretaries and Heads of Extra-ministerial 
Departments and some Directors in the service to various foreign training programmes in reputable institutions including the Royal Institute for Public Administration (RIPA) in London, the Galilee College in Israel, the International Labour Organization (ILO) Training Centre in Turin, Italy, the University of Wisconsin, Milwaukee, USA. A number of others were sent to the prestigious Administrative Staff College of Nigeria (ASCON) and the Centre for Management Development (CMD), both in Lagos State. According to the then Head of Civil Service, Mrs. Grace Anwana, between 2007 and 2011, over 1018 officers were sponsored to various scientific and professional conferences, seminars and workshops while over 500 of them presented papers. A total of one thousand nine hundred and seventy (1970) workers were given approval for study leave, in-service training or part time study to improve them academically. Obviously, over ten thousand two hundred and sixty (10,260) officers of government, covering all grades and cadres have benefited from one form of training or the other (AKSG, 2012).

In its further determination to reposition the Akwa Ibom State Civil Service (bureaucracy) for effective and efficient performance, with regards to staff welfare, the state government has provided a workers' bus service in addition to its car loan policy to workers, while utility care have been provided to enhance the business of government. Befitting uniforms were procured and distributed to all government drivers to make them look neat, smart and happy while on duty. This is unprecedented. The government poised for democratic challenges, approved the road work for civil servants tagged "Jogging to serve better". This exercise has been sustained as a bi-monthly programme which has helped addressed the problems of stress and allied ailments associated with the sedentary nature of the work of the civil servants. These initiatives of government has gone a long way in creating a new mind-set in the people to see the bureaucracy or the civil service as an organization that is vibrant, result-oriented, people-centred and truly working towards effective service delivery of democratic gains to the citizens.

In an attempt to authenticate the above position and indeed the assumptions of this paper, the opinions of the local people was sought on whether they were satisfied with the performance of the state's bureaucracy vis-a-vis the implementation of people's oriented projects in their communities as a mark of good (democratic) governance in the state. A total of six (6) Local Government Areas were used for the study, with two (2) Local Government Areas selected from the three senatorial districts of Akwa Ibom State (Eket, Ikot Ekpene and Uyo). Consequently, thirty (30) individuals, (5 per local government) constituting the youth/community leaders, government appointees, members of the academia, students in tertiary institutions and others of voting age were randomly approached for their opinions. The interview result revealed as follows: 


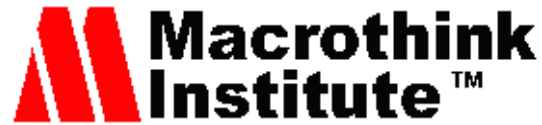

Journal of Public Administration and Governance ISSN 2161-7104 2018, Vol. 8, No. 3

Table 1. Level of citizens' satisfaction with bureaucracy and implementation of government programmes in Akwa Ibom State

\begin{tabular}{|c|c|c|c|c|c|}
\hline \multirow{2}{*}{$\begin{array}{l}\text { Senatorial } \\
\text { Districts }\end{array}$} & \multirow[t]{2}{*}{ LGAs } & \multirow{2}{*}{$\begin{array}{l}\text { No of persons } \\
\text { interviewed }\end{array}$} & \multicolumn{2}{|c|}{ Responses: } & \multirow[t]{2}{*}{$\%$} \\
\hline & & & Satisfied & Not satisfied & \\
\hline \multirow[t]{2}{*}{ Eket } & Onna & 5 & 5 & 0 & 100 \\
\hline & Okobo & 5 & 5 & 0 & 100 \\
\hline \multirow[t]{2}{*}{ Ikot Ekpene } & Ikot Ekpene & 5 & 5 & 0 & 100 \\
\hline & Essien Udim & 5 & 5 & 0 & 100 \\
\hline \multirow[t]{2}{*}{ Uyo } & Uruan & 5 & 5 & 0 & 100 \\
\hline & Uyo & 5 & 5 & 0 & 100 \\
\hline \multicolumn{2}{|l|}{ Total } & 30 & 30 & $\mathbf{0}$ & 100 \\
\hline
\end{tabular}

The above table indicates the level of people's satisfaction with government projects implemented in their respective communities in demonstration of good governance, through the Inter-Ministerial Direct Labour Co-ordinating Committee, manned by competent bureaucrats. All those interviewed expressed their satisfaction with the state government and the bureaucracy in the implementation of live-touching policies and programmes for the benefit of the citizenry and so declared their support for the government. This lend credence to the fact the more the government is successful in providing services to the people the higher the level of support it gets from the people. This, the government has done through the instrumentality of the state's bureaucracy, thus strengthening the bond between bureaucracy and democracy.

\section{Conclusion}

The bureaucracy in Akwa Ibom State has done fairly well as illustrated by numerous projects undertaken in the State by the government, prominent among them, construction of road networks, new Governor's lodge, Ibom International Airport, Le-meridien Hotel and Resort, Flyovers and specialist hospital, rural electrification projects, free and compulsory education for Akwa Ibom sons and daughters up to secondary level, among other issues. This is a testimony of successes recorded by the government in the implementation of development programmes to the people through the state's bureaucracy.

Nevertheless, a lot more need to be done in some areas to step up the effectiveness and efficiency of the bureaucracy towards effective service delivery. Thus, to further enhance the effectiveness and efficiency of the bureaucracy towards more democracy's dividend in the state, it is here re-stated that:

(i) The principle of transparency, probity and accountability should be made paramount in principle and in practice within and without the bureaucracy.

(ii) Meritocracy should constitute the basis for recruitment/appointment and postings within the civil service.

(iii) The re-branding campaign of the government should be sustained and specifically extended to civil service through seminars, workshops and symposiums.

(iv) Servicom which was established to ensure effective service delivery in the public service should be properly rejuvenated to its functions. 
(v) The instrument of checks and balances in the civil service should be objectively designed and enforced to address the issue of corruption within the system.

\section{References}

Achebe, C. (1983). The Trouble with Nigeria. Enugu: Fourth Dimension Publishers.

Adamolokun, L. (2002). Public Administration Reforms. In: Adamolokun, L. (Ed.), Public Administration in Africa. Ibadan: Spectrum Books Ltd.

Akanbi, M. M. (2004). Corruption, Accountability and Good Governance. Ibadan: Ibadan University Press.

Akpabio, G. O. (2007). Text of Inaugural Speech, 29 May.

Akpan, U. O. (2003). Introduction: Nigeria and the Spirit of Democracy. In: Akpan, O. (Ed.), The Art and Science of Politics: Essays in Honour of Alhaji Chali Umar Na Abba. Port Harcourt: Footsteps Publications.

Akwa Ibom State Government (2004). Akwa Ibom State Economic Empowerment and Development Strategy (AK-SEEDS) Volume 1: The Development Framework of Akwa Ibom State. Uyo: Ministry of Economic Development.

Akwa Ibom State Government (2012). Akwa Ibom State Civil Service Handbook. Uyo: Government Press.

Akwa Ibom State Government (2016). Akwa Ibom State Civil Service Commission Annual Report. Uyo: Government Press.

Cohen, K. (1971). Democratic Athens. Georgia: University of Georgia Press.

Diamond, L. (1989). Beyond Autocracy: Prospects for Democracy in Africa. Atlanta: Carter Center.

Diamond, L. (1994). Rethinking Civil Society: Towards Democratic Consolidation. Journal of Democracy, 8(2), 1-19.

Eminue, O. (2005). Introduction to Political Science. Calabar: Clear Lines Publications.

Erunke, C. E. (2012). Reconsolidating Democratic Governance in Nigeria: Analysis and Suggestions. African Journal of Social Sciences, 2(2), 67-73.

Eteng, I. A. (1987). The Political Economy of Contemporary Nigeria Public Service. Owerri: Staff Development Centre.

Eyibo, E. (2000). Embracing Positive Work Ethics: The Role of the Public Service. A Paper Presented at a Seminar on Positive Work Ethics for Civil Servants in Akwa Ibom State held at Civil Service Auditorium, State Secretariat, Uyo, 13-14 April.

Fayol, H. (1930). General and Industrial Management. London: Pittman 


\section{Macrothink}

Journal of Public Administration and Governance ISSN 2161-7104 2018, Vol. 8, No. 3

Frank. E. O. (2007). Public Administration: Theories and Practices: A Text for African Universities. Benin-City: Ethiope Publishing Corporation.

Heater, D. B. (1964). Political Ideas in the Modern World. London: George Harrap.

Held, D. (1993). Prospect for Democracy: North, South, East and West. Cambridge: Polity Press.

Ikelegbe, A. (2006). Public Policy Analysis: Concepts, Issues and Cases. Lagos: Imprint Services.

Ita, V. E., Edet, L. I., \& Bassey, M. E. (2016). The Impacts of the National Rebirth Programme on the Moral Character of Nigerian Civil Service Employees (1999-2011): Akwa Ibom State Perspective. Global Journal of Human Social Science, 16(3), 17-28.

Locke, J. (1965). Two Treaties of Government. New York: New American Library.

MacOgonor, C. U., \& Okodudu, S. (2007). Public Administration and Policy Implementation: The Bane of Nigerian Development. Journal of Public Policy, 1(1), 183-207.

Naidu, S. P. (1996). Public Administration: Concepts and Theories. New Delhi: New Age International Publishers.

National Population Commission (NPC). (2006). National Census Report 2006. Abuja: NPC.

Nwosu, H. N. (1985). Political Authority and the Nigerian Civil Service. Enugu: Fourth Dimension.

Obi, E. A., \& Nwanegbo, C. J. (2006). Development Administration: Theory and Practice. Onitsha: Book Point.

Obi, E., \& Dalhatu, M. (2007). Current Practices and Problems of Nigerian Public Administration. Onitsha: Book Point.

Olugbemi, S. O. (1979). The Civil Service: An Outsider's View. In: Oyeriran, O. (Ed.), Nigerian Government and Politics under Military Rule 1966-1979. Ibadan: Oyediran Consult International.

Omotola, J. S. (2004). Is Nigeria's Democracy Working? A Paper Presented at a Two-day Workshop on Socio-Anthropological Perspective on Africa's Development, University of Port Harcourt, 13-14 October.

Page, E. (1988). Political Authority and Bureaucratic Power: A Comparative Analysis. New York: Wheat Sheaf Books.

Pugh, D. S. (1996). Modern Organization Theory: A Psychological and Sociological Study. Sociological Bulletin, 66(21), 235-251.

Ritzer, G. (1996). Bureaucratization: Making Life More Rationale. Thousand Oaks, California: Pine Forge Press.

Satori, G. (1965). Democratic Theory. New York: Praeger Publications. 


\section{Macrothink}

Journal of Public Administration and Governance ISSN 2161-7104 2018, Vol. 8, No. 3

Shively, P. (2001). Power and Choice: An Introduction to Political Science. New York: McGraw-Hill.

Thompson, V. A. (1961). Modern Organization. New York: Alfred A. Knopf Inc.

Umofia, D. (2005). The Nigerian Civil Servant: The Hope of the Nation. Ikot Ekpene: Annprince Nigeria Limited.

Uya, O., \& Okoro, J. (2002). Local Government Administration and Grassroots Democracy in Nigeria. Calabar: University of Calabar Press.

Weber, M. (1957). The Theory of Economic and Social Organization. Berkeley: Berkeley University Press.

\section{Copyright Disclaimer}

Copyright for this article is retained by the author(s), with first publication rights granted to the journal.

This is an open-access article distributed under the terms and conditions of the Creative Commons Attribution license (http://creativecommons.org/licenses/by/4.0/). 